\title{
Comparision of the periphyton inhabiting reed between floodplain lake and river
}

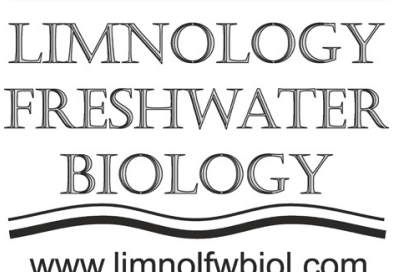

\author{
Bąkowska M.*, Mrozińska N., Szymańska M. \\ Department of Hydrobiology, Kazimierz Wielki University, Powstańców Wielkopolskich Av. 10, Bydgoszcz, 85090, Poland
}

\begin{abstract}
In 2018, on the biotic substrate formed by Phragmites australis in lotic (the Stupia River) and lenitic oxbow lake (OLB) ecosystems we observed the development of epiphytic organisms from all the trophic levels (producers, consumers, decomposers). In both ecosystem types the producers were represented mainly by diatoms, which were more abundant in the river, where the average density of epiphytic algae was 1.5-fold higher than in the oxbow. Epiphytic microfauna on reed substrate included 14 taxa both in the river and the oxbow lake but it developed better in the oxbow and reached 3.5-fold higher density than in the river. As for macrozooperiphyton, the lenitic ecosystem was predominated by Nematoda $(D=84 \%)$ while the lotic ecosystem by Rotatoria $(D=50 \%)$. Large epiphytic animals were present only on reed growing along the bank of the Słupia River. That component of zooperiphyton was represented only by 3 taxa, among which the most abundant was Asellus aquaticus $(\mathrm{D}=59 \%)$.
\end{abstract}

Keywords: periphyton, structure, reed, oxbows, River, Słupia

\section{Introduction}

Periphyton (biofilm) is a form of concentration of bacteria, fungi, algae and animals in the form of thin sediments formed on various surfaces in contact with non-sterile water. In this way, it is a formation formed in all types of aquatic ecosystems on biotic and abiotic substrates, influencing the natural processes of water self-purification. Despite the presence of periphyton in all types of aquatic ecosystems, the structure and functioning of the periphyton still need to be thoroughly studied. Currently, we have information on the qualitative and quantitative structure of the reed inhabiting reeds in estuarine lakes and dam reservoirs, however, there is very little information on this formation occurring in rivers (Piesik and WawrzyniakWydrowska, 2003) The floodplains are important element of the functioning of river valleys, which can purify river waters thanks to the periphyton inhabiting various substrates, including biotic ones created by reeds.

The structure of the periphyton is determined by many factors, among which we can identify hydrological elements, chemical elements, trophic interactions The aim of the study was to compare the quantitative and qualitative structure of periphyton inhabiting submerged reed shoot fragments in the river and the oxbow lakes on the example of the Słupia River.

\section{Materials and methods}

Reed samples covered with periphyton were collected in four seasons in 2018, at 6 study sites: 3 in a selected old oxbowl lake and 3 in the river Stupia. Fragments of live reed were collected by cutting out 3 Phragmites shoots at each site. The underwater part of the reed was cut and then covered with a plastic tube, which was closed from below when the stem was taken outside the water. In the laboratory, 3 sections of 10-12 cm length were cut from each shoot: the upper part of the shoot below the water surface, the middle part and the upper part ( 9 subsamples in total). The collected fragments were conservedh on site in $8 \%$ formalin solution or $98 \%$ ethyl alcohol solution. In the laboratory, the length and width of substrates were accurately measured and their surface was determined.

The next stage was scrubbing off the growths with a brush, and then rinsing the whole thing through a plankton mesh of $60 \mu \mathrm{m}$ mesh size and placing it in a measuring cylinder of $25-100 \mathrm{ml}$ volume, depending on the density of the material studied. After it was mixed evenly in the cylinder, a pipette of three subsamples of $1 \mathrm{ml}$ each was taken and placed in the plankton chamber. Under the microscope, its composition was examined by quantitative and qualitative analysis of the collected material according to the K. Obolewski et al. (2011) methodology.

*Corresponding author.

E-mail address: bakowska.martyna@ukw.edu.pl (M. Bąkowska)

(C) Author(s) 2020. This work is distributed under the Creative Commons Attribution 4.0 License. 
In order to organize and properly interpret the obtained data, appropriate zoocenotic indicators were used, i.e. dominance index (D, \%) and Simpson's $\alpha$-diversity index (D). The one-way ANOVA KruskalWallis was used to determine the isotivity of differences in the periphyton structure.

\section{Results}

The Periphiton settling reed in old river beds from 5 to 15 taxons and in the river from 7 to 13 taxons. In the first seasons of the study (autumn-winter), a greater number of taxons were observed in the old river bed while in spring and summer in the old river bed (Table 1).

The microzooperiphyton inhabiting reed in the oxbow lake bed consisted of 14 taxons, among which eudominant positions were reached by Nematoda $(D=84 \%)$, while Rotifera $(D=5 \%)$ and Peritricha $(\mathrm{D}=3 \%)$ also gained significant shares. In autumn Nematoda dominated completely, and in winter they were accompanied by Rotatoria, in spring and summer Peritricha joined them (Fig. 1A). On the reed in the river in microzooperiphyton the Rotatoria $(D=50 \%)$, Peritricha $(D=23 \%)$, Testacea $(D=12 \%)$ and Nematoda $(D=10 \%)$ had significant share. The remaining taxons were not significant in the studied formation. In autumn, winter and spring the Rotifera dominated in the microzooperiphyton on the reed, and in summer the Peritricha (Fig. 1A). In the oxbow lake, this part of the periphyton was dominated by Nematoda $(D=84 \%)$, Rotifera $(D=5 \%)$ and Peritricha ( $D=2 \%$ ), and the other taxons represented $<2 \%$ of the total density of this periphyton aggregation. In autumn, Nematoda completely dominated on reed substrate and in the other seasons they were accompanied by Rotifera, slightly dominating the density in winter and summer.

Comparing the microfauna density in individual seasons between the river and the oxbow lakes, it turned out that in the only autumn there were statistically significant differences $(p>0.05)$, which was caused by the very high abundance of Nematoda (Table 1). In the other seasons microzooperiphyton achieved similar values in the river and oxbow lakes, with a slight advantage in the volatile ecosystem. In general, this component of periphyton developed better in the oxbow lakes, reaching a density 3.5 times higher than in the river.

Larger periphyton animals were not observed on the biotic substrate in the oxbow lakes and in the river their density was highest in summer (Table 1). In the river the macrozooperiphyton was composed of three taxons: Asellus aquaticus ( $\mathrm{D}=59 \%)$, Chironomidae larvae $(D=33 \%)$ and Bezzia sp. $(D=8 \%)$. Only in autumn no representative of the macro-fauna was found, in winter A.aquaticus dominated completely, in spring Bezzia sp. and only in summer A.aquaticus and Chironomidae larvae with a slight domination of Isopoda were found (Fig. 1B).

Among the microphytoperiphyton in the oxbow lakes, Bacillariophyta dominated $(D=94 \%)$, accompanied by different Chlorophyta $(\mathrm{D}=5 \%)$ and its representative Scenedesmus sp. $(D=1 \%)$. In all seasons only Bacillariophyta were observed in all seasons, except in spring, where a small Chlorophyta density was found (Table 1). In the river, the planting algae

Table. Average density of micro-. macrozooperiphyton (indiv. $\mathrm{m}^{-2}$ ) and phytoperiphyton (mln cells $\mathrm{m}^{-2}$ ) and $\alpha$-diversity Simpson index (D) for periphyton inhabitinh reed in oxbow lake (OLS) and the Słupia River (RS) with one-way ANOVA KruskalWallis test.

\begin{tabular}{|c|c|c|c|c|c|c|c|c|c|}
\hline & \multicolumn{2}{|c|}{ Spring } & \multicolumn{2}{|c|}{ Summer } & \multicolumn{2}{|c|}{ Autumn } & \multicolumn{2}{|c|}{ Winter } & \multirow[t]{2}{*}{$p$} \\
\hline & OLS & $\mathrm{RS}$ & OLS & $\mathrm{RS}$ & OLS & RS & OLS & $\mathrm{RS}$ & \\
\hline No of taxa & 11 & 8 & 15 & 13 & 5 & 7 & 7 & 9 & 0.54 \\
\hline$\alpha$-diversity (D) & 0.482 & 0.504 & 0.257 & 0.424 & 0.872 & 0.248 & 0.487 & 0.396 & 0.04 \\
\hline \multicolumn{10}{|c|}{ Phytoperiphyton $\left(10^{6}\right.$ cell $\left.\mathrm{m}^{-2}\right)$} \\
\hline Bacillariophyta & 11,131 & 11,029 & 13,241 & 26,739 & 3,063 & 4,837 & 6,500 & 4,821 & 0.01 \\
\hline Cyanophyta & 0 & 0 & 0 & 2283 & 0 & 279 & 0 & 0 & 0.59 \\
\hline Chlorophyta & 357 & 0 & 0 & 435 & 0 & 0 & 0 & 0 & 0.70 \\
\hline \multicolumn{10}{|c|}{ Microzooperifiton (indiv. $\mathbf{m}^{-2}$ ) } \\
\hline Protozoa & 1,190 & 539 & 1,944 & 3,916 & 315 & 2,464 & 777 & 655 & 0.02 \\
\hline Rotifera & 595 & 3,039 & 2,407 & 1,739 & 135 & 5,116 & 722 & 1,071 & 0.02 \\
\hline Nematoda & 595 & 735 & 2,315 & 978 & 61,802 & 162 & 611 & 298 & 0.01 \\
\hline Tardigrada & 357 & 196 & 278 & 0 & 0 & 0 & 0 & 0 & 0.36 \\
\hline Oligochaeta & 59 & 0 & 555 & 435 & 0 & 39 & 0 & 0 & 0.22 \\
\hline Cladocera & 0 & 0 & 1071 & 109 & 0 & 0 & 0 & 0 & 0.47 \\
\hline Copepoda & 357 & 0 & 1111 & 109 & 315 & 0 & 55 & 178 & 0.04 \\
\hline Hydrachnella & 0 & 0 & 0 & 0 & 0 & 0 & 0 & 59 & 0.78 \\
\hline \multicolumn{10}{|c|}{ Macrozooperifiton (indiv. $\mathbf{m}^{-2}$ ) } \\
\hline Isopoda & 0 & 0 & 0 & 326 & 0 & 0 & 0 & 59 & 0.41 \\
\hline Insecta & 0 & 49 & 0 & 217 & 0 & 0 & 0 & 0 & 0.36 \\
\hline
\end{tabular}



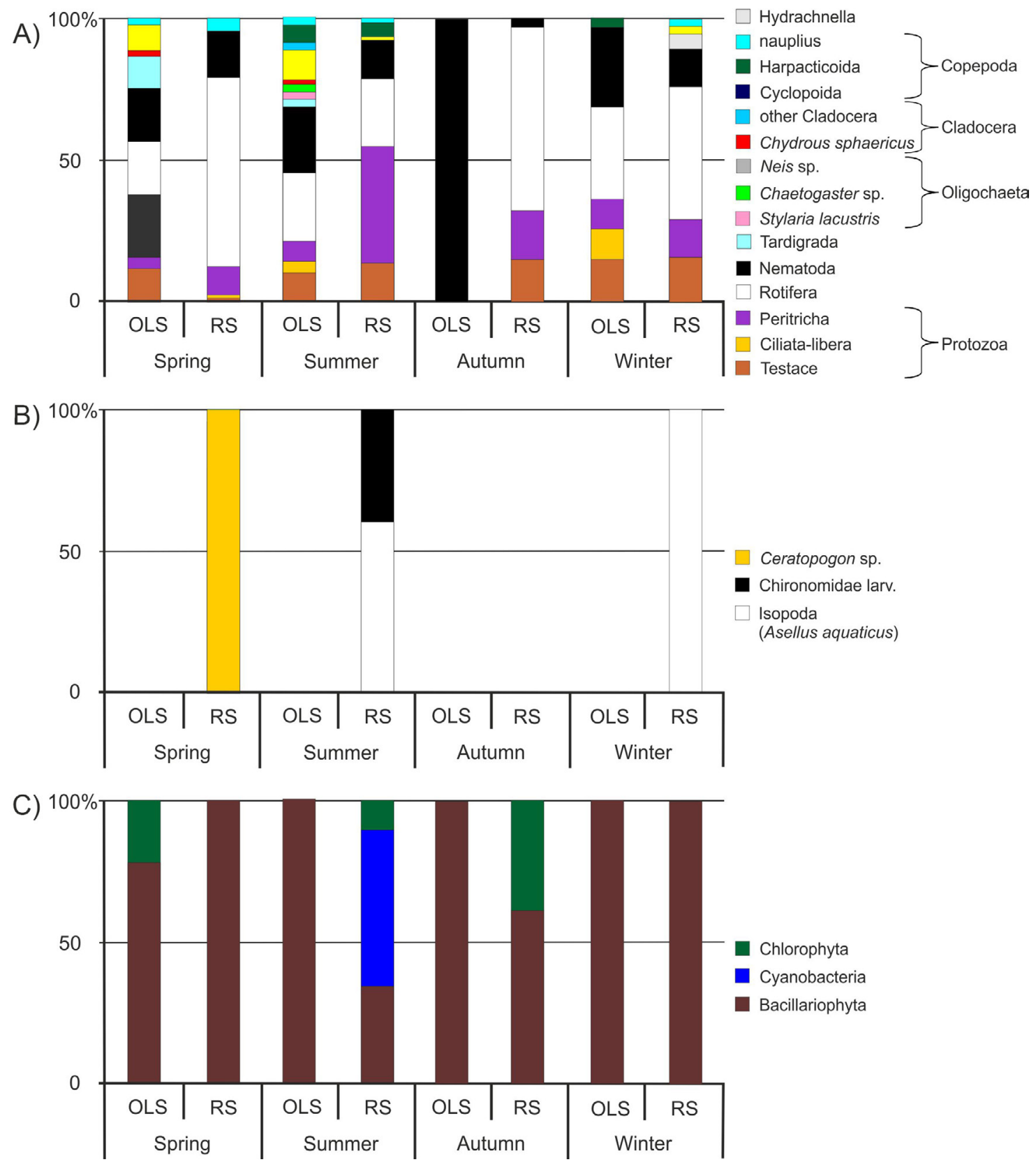

Fig.1. Domination structure (D, \%) of periphyton inhabiting reed in oxbow lake (OLB) and the River Słupi.

were represented by Bacillariophyta, Chlorophyta and Cyanobacteria, while Bacillariophyta dominated the reed substrate especially in winter and spring (Fig. 1C). In autumn, diatoms were accompanied by cyanobacteria and in summer, additionally by Chlorophyta, but these were trace amounts below 10\% (Fig. 1C).

Simpson's diversity indicated that the most attractive seasons for periphyton development in the oxbowl lake were in autumn and the worst in summer, while in spring and autumn respectively. The analysis of the agglomeration taking into account Bray-Curtis distances showed a significant impact of seasonality on the growth organisms, especially in winter and spring by grouping samples from the river and the oxbow lakes. Summer and autumn results were significantly different, but the most different quantitative structure of periphyton was observed in the oxbow lakes in autumn.

\section{Discussion}

The flowing waters bring with them large amounts of nutrients that provide food for periphyton organisms, mostly those feeding on the basis of filtration or sedimentation (Peritricha, Rotifera). This has been confirmed by research on this reed formation in other rivers both in temperate climates, e.g. the Odra river, and in the Mediterranean zone Evinios (Greece), (Piesik and Wawrzyniak-Wydrowska, 2003). However, regardless of the size of the rivers and the degree of their pollution, the number of identified taxons is similar and ranges from 14 in Stupia to 10 in the Oder.

The value of macrozooperiphyton density in the river is very low, many times lower than in the Odra river (Piesik and Wawrzyniak-Wydrowska, 2003). This biofouler component was represented mainly by Isopoda (Asellus aquaticus), which was 
not observed in the other lake ecosystems studied. A typical macrozooperiphyton taxon predominating on reed substrate is usually the larvae Chironomidae. The presence of representatives of Ceratopogonidae (Bezzia sp.) is recorded in the periphyton on biotic substrates but with low density, while in the Słupia river they dominate the macrozooperiphyton in spring.

In the research on the periphyton colonizing reed in the Stupia River valley in the area of the Krzynia dam reservoir in the „Dolina Słupi” Landscape Park, the microzooperiphyton was represented by a smaller number of taxons (10), among which Peritricha dominated ( $\mathrm{D}=35 \%)$, (Obolewski and Piesik, 2005). Below the studied reservoir in the Słupia River, the share of this taxon on the reed decreased to $23 \%$ of the total number of microzooperiphyton, while in the oxbow lakes it constituted only 2.5\%. These organisms feed by sedimentation of the biosestone, which is carried in large amounts by river waters and is accumulated in dam reservoirs.

In the Krzyński reservoir above the studied fragment of the Słupia River valley, macrozoperiphyton was represented mainly by Chironomidae larvae $(\mathrm{D}=95 \%)$ and accompanied by Cordylophora caspia cavities (Obolewski and Piesik, 2005). The reed in the river below the water was dominated by the Asellus aquaticus $(D=59 \%)$ and the Chironomidae larvae represented only $33 \%$. Both of these species feed on the plant algae, whose density was 46 times higher in the river than in the body of water.

Both in the dam reservoir, oxbow lakes and the Słupia River itself, Bacillariophyta achieved a definite dominance among phytoperiphyton. This is a common situation observed also in other types of water ecosystems. They are accompanied by chlorophyta and cyanobacteria which, obtain low density. No representatives of Cyanophyta were found in the oxbow lakes, which may be caused by strong competition of aquatic plants for nitrogen components in these ecosystems. The development of phytoplankton and total domination of Bacillariophyta in periphyton in lenithic ecosystems prevents the existence of cyanobacteria.

\section{Conclusions}

Studies of reeds have proven that they provide a convenient basis for the development of the complex of plant organisms, both in lotic and lentical ecosystems. The study of reeds showed that they were a convenient substrate for the development of the reed community, both in oxbow lakes and river. However, both macrozooperiphyton and phytoperiphyton obtained higher density in lotic environment.

\section{Acknowledgments}

The project is financed under the program of the Minister of Science and Higher Education (Poland) under the name "Regional Initiative of Excellence" in 2019-2022 project number 008/RID/2018/19.

\section{References}

Piesik Z., Wawrzyniak-Wydrowska B. 2003. Organizmy poroślowe (perifiton) zasiedlający trzcinę Phragmites australis w ujściowym odcinku rzeki Odry i Gunicy. In: Rogalska S., Domagała J. (Eds.), Człowiek i środowisko przyrodnicze Pomorza Zachodniego. Cz. I. Środowisko biotyczne [Man and the natural environment of West Pomerania. Part I. Biotic environment]. Szczecin, pp. 161-172. (in Polish)

Obolewski K., Piesik Z. 2005. Epiphytic organisms (periphyton) inhabiting biotic substrate in Lake „Dolina Słupi" Landscape Park. Polish Journal of Natural Sciences 18(1): 117-131.

Obolewski K., Skorbiłowicz E., Skorbiłowicz M. et al. 2011. The effect of metals accumulated in reed (Phragmites australis) on the structure of periphyton. Ecotoxicology and Environmental Safety 74(4): 558-568. DOI: 10.1016/j. ecoenv.2011.01.024 